\title{
Analysis of the Effect of Fraud Pentagon Factors on Fraudulent Financial Statement with Audit Committee as Moderating Variable
}

\author{
Krisna Dewi ${ }^{* 1}$ and Indah Anisykurlillah ${ }^{2}$ \\ ${ }^{1}$ PT Putra Wijayakusuma Sakti, Semarang, Indonesia \\ ${ }^{2}$ Accounting Department, Faculty of Economics, Universitas Negeri Semarang, Indonesia
}

\section{ARTICLE INFO}

\section{Article History:}

Received January $28^{\text {th }}, 2021$

Accepted March $7^{\text {th }}, 2021$

Available March 15 ${ }^{\text {th }}, 2021$

\section{Keywords:}

Fraudulent Financial

Statement; Fraud Pentagon;

Audit Committee

\begin{abstract}
This study aims to analyze the effect of fraud pentagon on fraudulent financial statements with audit committee as moderating variable. The population of this study was the property, real estate, and construction companies listed on the Indonesia Stock Exchange during 2016-2018. The sampling technique used purposive sampling and obtained 52 companies with 156 units of analysis. The data were analyzed using logistic regression analysis by IBM SPSS Ver.26. The results showed that company growth had a positive effect on fraudulent financial statements. Meanwhile, the effectiveness of supervision, quality of external auditors, the experience of directors, and CEO duality did not affect fraudulent financial statements. Audit committee significantly moderated the effect of company growth, the effectiveness of supervision, and the experience of directors on fraudulent financial statements. However, audit committee did not moderate the effect of quality of external auditors and CEO duality on fraudulent financial statements. This study concludes that the fraudulent financial statements will be higher when the company growth is higher. Audit committee weakens the effect of company growth, the effectiveness of supervision, and the experience of directors on fraudulent financial statements.
\end{abstract}

(C) 2021 Published by UNNES. This is an open access article under the CC BY license (http://creativecommons.org/licenses/by/4.0/)

\section{INTRODUCTION}

Financial statements are issued by companies to present financial information that is useful for decision-makers. In general, companies present financial statements honestly and fairly in accordance with the corporate actual position. However, the financial statements presented by companies sometimes contain misstatements. Association of Certified Fraud Examiners (ACFE) defined fraudulent financial statements as a scheme that describes employees or management taking deliberate actions by manipulating financial statements thus causing misstatements and hiding information that can affect decision-making.

Based on the survey conducted by ACFE in 2018, the fraudulent financial statement gives the largest loss impact compared to other types of fraud, amounting to $\$ 800,000$. Apart from being seen from the magnitude of the impact of the losses, when seen from the frequency of cases, fraudulent financial statements have an increasing number of cases occurring from year to year as seen

\footnotetext{
*E-mail: krisnadewi345@gmail.com

_Address: Jln. Tugu Industri 1 No 12, Randugarut, Tugu, Semarang, Indonesia
}

DOI 10.15294/aaj.v10i1.44520 in Figure 1.

The property, real estate, and construction sectors are some of the sectors that are vulnerable to fraudulent financial statement practices. Saleh (2010) stated that there is a positive relationship between the construction industry and misstatements committed by companies. During 2016-2018, this sector was ranked 3rd in the highest number of case complaints according to the Indonesian Consumers Foundation (YLKI). One of the companies that had been involved in fraudulent financial statement cases was PT Hanson Internasional. The fraudulent financial statement practice was committed

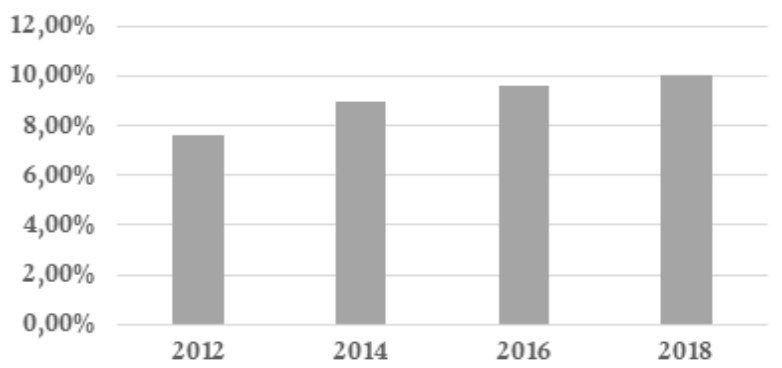

Figure 1. The Frequency of Fraudulent Financial Statement Occurrence in the World

Source: ACFE, Report to the Nation on Occupational and Abuse

p-ISSN 2252-6765 e-ISSN 2502-6216 
by manipulating the income accounts contained in the report for the period December 31, 2016. The revenue was recognized on a full accrual basis so that the income account did not reflect the actual condition. This was due to a violation of supply contracts amounting to Rp732 billion. As a result, the income account was overstated by Rp.613 billion (CNN Indonesia, 2019).

Undetected fraudulent financial statements have an adverse effect on users of financial information. Cressey (1950) developed methods of fraud detection by identifying factors that cause fraud including pressure, opportunity, and rationalization. Wolfe \& Hermanson (2004) added capability as one of the elements that drives fraud which is then known as diamond fraud. Then, the fraud theory developed into fraud pentagon developed by Marks (2012). The fraud pentagon elements consist of pressure, opportunity, rationalization, competence, and arrogance. Several studies have been carried out but keep showing mixed results. This study examines the factors that influence the occurrence of fraudulent financial statements based on the fraud pentagon theory.

In this study, pressure is proxied by company growth variable. Research conducted by Prasetyo (2014) indicates that company growth has a negative effect on fraudulent financial statements. However, Carcello \& Nagy (2004) found that company growth has a positive effect on fraudulent financial statements. Opportunity is proxied by the effectiveness of supervision. Research conducted by Kusumawardhani (2013) indicates that the effectiveness of supervision has a negative effect on fraudulent financial statements. However, Setiawati \& Baningrum (2018) found that the effectiveness of supervision does not have an effect on fraudulent financial statements. Rationalization is proxied by the variable of external auditor quality. Research conducted by Aini \& Sulhani (2017) indicates that auditor quality does not have an effect on fraudulent financial statements. However, Apriliana \& Agustina (2017) found that auditor quality has a negative effect on fraudulent financial statements. Competence is proxied by the variable of director experience. Research conducted by Ratnasari \& Solikhah (2019) indicates that the competency factor does not have an effect on fraudulent financial statements. Meanwhile, Uciati \& Mukhibad (2019) found that the competency factor has a positive effect on fraudulent financial statements. Arrogance is proxied by the variable of CEO duality. Research conducted by Carcello \& Nagy (2004) indicates that CEO duality has a positive effect on fraudulent financial statements. However, Yang et al. (2017) found that CEO duality has a negative effect on fraudulent financial statements. The inconsistencies in the previous research findings encourage the researchers to add audit committees as a moderating variable to the study which is expected to strengthen or weaken the relationship between independent variables and fraudulent financial statements.

This study aims to analyze the effect of the fraud pentagon factors on fraudulent financial statements with audit committee as moderating variable in the property, real estate, and construction sector companies listed on the Indonesia Stock Exchange in 2016-2018.
The difference between this study and the previous research is the use of research variables. First, this study uses the variable of director experience to proxy the competency factor as measured by the average work period of the board of directors. Second, the use of industry-specialist auditors to measure the quality of external auditors which in the previous studies was mostly measured by the size of KAP.

This study uses agency theory to explain the relationship between the independent variable and the dependent variable. Agency theory put forward by Jensen \& Meckling (1976) explains that there are differences in interests between management and company owners. The owner of the company acts as a principal, while management acts as an agent. Dobson (1993) explained that the agency relationship creates two problems namely adverse selection (occurs when the owner of the company has less information than management) and moral hazard (arises because the owner of the company does not know all the activities carried out by management). This problem drives management to hide some information that is unknown to the owner of the company so that management acts outside of ethics and norms, one of which is manipulating financial statements.

Agency theory states that company owners will provide incentives to management for the performance that has been done. To get high incentives, management will try to maintain company performance, one of which can be seen from the company's growth. Company growth is a condition that describes the entity's ability to maintain its position in the economy (Saputri et al., 2017). The growth ratio which is getting lower indicates that the company is in poor condition. Albrecht et al.(2010) stated that in case where the company's growth is not above the industry average, management is driven to manipulate financial statements with the aim of presenting the company's performance to keep looking good. Research conducted by Prasetyo (2014) and Saputri et al. (2017) prove that company growth has a negative effect on fraudulent financial statements.

\section{$H_{1}$ : company growth has a negative effect on fraudu- lent financial statements}

The effectiveness of supervision is an effective supervisory mechanism accompanied by a supervisory unit to monitor company operations (Rahman \& Anwar, 2014). In agency theory, company owners do not have as much information as management does. Thus, supervision is needed to ensure that management has acted in the interests of the company owner. In this stu$\mathrm{dy}$, the effectiveness of supervision is measured by the proportion of the number of board of independent commissioners. The board of independent commissioners is a party that has no affiliation with the company so it is free from business interests, which encourages acting solely for the benefit of the company and can minimize the occurrence of fraud (Narolita \& Krisnadewi, 2016). Research conducted by Kusumawardhani (2013) and Smaili \& Labelle (2016) prove that the effectiveness of supervision has a negative effect on fraudulent financial statements. 
$\mathrm{H}_{2}$ : the effectiveness of supervision has a negative effect on fraudulent financial statements

The quality of external auditor is defined as the possibility that given audits will detect fraud that occur in clients' company system and reveal these frauds (Halbouni et al., 2016). Agency relationship raises several problems, one of which is that shareholders do not see all the activities carried out by management so there is a possibility that management has violated the contract and acted outside of the ethics. In this study, auditor quality is measured using industry-specialist auditors. With their knowledge and experience, industry-specialist auditors can better understand the client's industry conditions. If the company's financial statements are audited by industry-specialist auditors, management will rethink when they want to commit fraud and tend to minimize fraudulent financial statement practices. Research conducted by Amijaya \& Prastiwi (2013) and Yang et al.(2017) prove that the quality of external auditors has a negative effect on fraudulent financial statements.

$\mathrm{H}_{3}$ : The quality of external auditors has a negative effect on fraudulent financial statements

The experience of directors is defined as how long a member of the board has served as director of the company concerned. Company management in this case acts as an agent in charge of managing the company. Wolfe \& Hermanson (2004) stated that a person with great potential to commit fraud is a person who is good at understanding and taking advantage of weaknesses in internal control and utilizing his position to manipulate. The longer a person has served as a board of directors, the broader the knowledge related to the company's business processes so that he will be better able to identify internal control weaknesses and take the opportunity to commit fraudulent financial statements. Uciati \& Mukhibad (2019) and Indarto \& Ghozali (2016) prove that the capability factor has a positive effect on fraudulent financial statements.

\section{$\mathrm{H}_{4}$ : the experience of the board of directors has a posi- tive effect on fraudulent financial statements}

CEO duality is a CEO who has multiple positions in the company. In Indonesia, public companies adopt a two-tier board system. Thus, CEO duality in this study is defined as a situation where there is a family relationship between the board of directors and the board of commissioners. This condition results in the number of cases where the child serves on the board of directors and the parent is on the board of commissioners. This results in centralized power so that arrogance is higher. This attitude made someone feel that he has the right to do something and considers that the prevailing internal controls are not a barrier. Thus, this condition will trigger management discretion, which is a condition where management has the freedom to consider and make decisions (Putri \& Deviesa, 2017). The existence of less effective managerial power and the supervisory function of the board of commissioners can lead to fraud with the aim of maximizing personal gain. Rese- arch conducted by Carcello \& Nagy (2004) and Yang et al.(2017) prove that CEO duality has a positive effect on fraudulent financial statements.

\section{$\mathrm{H}_{5}$ : CEO duality has a positive effect on fraudulent fi- nancial statement}

The lower sales growth ratio is considered to increase the pressure to manipulate financial statements. Therefore, a monitoring system is needed to ensure that financial information is reported honestly (Ika \& Ghazali, 2012). Audit committee is a part of the supervisory mechanism that monitors the process of preparing corporate financial statements. The audit committee has the authority to review financial information before it is submitted to external parties of the company so that when there is anomalous information, it can be immediately traced. Thus, the audit committee weakens the pressure factor on fraudulent financial statements (Santoso, 2019).

\section{$\mathrm{H}_{6}$ : Audit committee weakens the effect of company growth on fraudulent financial statements}

The proportion of boards of independent commissioners that is getting higher is considered to minimize the tendency of companies to manipulate financial statements. In addition, there is a need for a monitoring system to help ensure that the contents of financial reports do not mislead information users (Mardiani et al., 2017). Audit committee is a company organ that works under the board of commissioners. Thus, the existence of the audit committee is to assist the board of commissioners, especially concerning the supervision of company financial reporting (Ika \& Ghazali, 2012). Thus, the relationship of the effectiveness of supervision in minimizing fraudulent financial statements will be stronger with the presence of the audit committee (Sugita, 2018).

\section{$\mathrm{H}_{7}$ : audit committee strengthens the effect of the ef- fectiveness of supervision on fraudulent finan- cial statements}

The use of industry-specialist auditors is considered to be able to minimize the tendency of companies to manipulate financial statements (Amijaya \& Prastiwi, 2013). In addition, an effective monitoring system is still needed to help ensure that the financial reporting process does not contain misstatements. Audit committee has the authority to give recommendations on the use of the services of qualified external auditors to ensure that financial statements are presented fairly (Ika \& Ghazali, 2012). Thus, the audit committee strengthens the effect of external auditor quality in minimizing fraudulent financial statements (Santoso, 2019).

\section{$\mathrm{H}_{8}$ : audit committee strengthens the effect of the ex- ternal auditor quality on fraudulent financial statements}

The average work period of the board of directors which is getting higher is considered to increase the tendency of companies to manipulate financial statements. Therefore, a monitoring system is needed that can ensure that management reports financial information ac- 
cording to the actual conditions of the company. Audit committee is a party that assists the board of commissioners in monitoring management responsibilities related to the preparation of corporate financial reports (Ika \& Ghazali, 2012). Thus, the presence of the audit committee will weaken the effect of the capability factor on fraudulent financial statements (Mardiani et al., 2017).

\section{$\mathrm{H}_{9}$ : audit committee weakens the effect of the board of director experience on fraudulent financial state- ments}

The existence of a kinship relationship between the board of directors and the board of commissioners is considered to increase the tendency of companies to manipulate financial statements. A monitoring system is needed to ensure financial information is properly reported. One part of this mechanism is audit committee. Audit committee has the authority to give recommendations to the board of commissioners if there is a conflict of interest, one of which is due to family relationships (Ika \& Ghazali, 2012). Thus, the relationship between CEO duality in influencing the occurrence of fraudulent financial statements will be weaker with the presence of the audit committee (Santoso, 2019).

\section{$\mathrm{H}_{10}$ : audit committee weakens the effect of CEO dual- ity on fraudulent financial statements}

\section{RESEARCH METHODS}

This research was a quantitative study using secondary data obtained from audited annual reports and published on the Indonesia Stock Exchange website. The data collection used documentation techniques. The population of this study was the property, real estate, and construction sector companies listed on the IDX during 2016-2018. The sampling technique used purposive sampling technique resulting in 52 companies with 156 units of analysis. The criteria for determining the sample can be seen in table 1 .

This study used one dependent variable, five in-

Table 1. Research Sample Criteria

\begin{tabular}{clc}
\hline No & \multicolumn{1}{c}{ Explanation } & Total \\
\hline 1. & $\begin{array}{l}\text { The number of the property, real estate, } \\
\text { and construction sector companies listed }\end{array}$ & 59 \\
on the IDX during 2016-2018 & \\
2. $\begin{array}{l}\text { The property, real estate, and construc- } \\
\text { tion sector companies that did not pub- }\end{array}$ & 1 \\
lish audited annual reports for the 2016- & \\
2018 period & \\
3. $\begin{array}{l}\text { The property, real estate, and construc- } \\
\text { tion sector companies that did not pro- }\end{array}$ & 6 \\
vide data related to the research variables & \\
4. $\begin{array}{l}\text { The number of companies in the prop- } \\
\text { erty, real estate and construction sectors }\end{array}$ & 52 \\
becoming samples & \\
5. Research periods (2016-2018) & 3 \\
6. Total analysis units (x 3) & 156 \\
\hline
\end{tabular}

Source: Secondary data processed, 2020 dependent variables, and one moderating variable, as shown in table 2 . The measurement of fraudulent financial statements using $\mathrm{m}$-score is calculated by the formula 1.

$$
\begin{aligned}
M \text {-Score } & =-4.84+0.920 D S R I+0.528 G M I \\
& +0.404 A Q I+0.892 S G I+0.115 D E P I \\
& -0.172 S G A I-0.327 L V G I+4.697 T A T A \quad . .1
\end{aligned}
$$

The hypothesis testing used logistic regression analysis techniques. Meanwhile, the moderation test used the absolute difference value test. The significance level used was 5\%. The data were analyzed using IBM SPSS Ver26. The use of logistic regression in this study was due to the measurement scale for the dependent variable in the form of a nominal scale. The logistic regression analysis technique does not require a classical assumption test. Instead, a model feasibility test was conducted before the hypothesis was tested.

\section{RESULTS AND DISCUSSIONS}

In the logistic regression analysis, the first thing to do is to assess the feasibility of the model as seen from the -2 loglikelihood. Based on the statistical results, the initial -2loglikelihood value is 213.149 while the final -2loglikelihood value is 176.603 . These results indicate that there has been a decrease of 36.546 so it is concluded that the hypothesized model is fit with the data. Furthermore, assessing the feasibility of the model seen from the Hosmer and Lemeshow test, it is obtained a significance value of $0.875(>0.05)$. Thus, it is concluded that the regression model in this study is in accordance with the observational data and can be used for further analysis. A summary of the hypothesis testing results can be seen in table 3 .

\section{The Effect of Company Growth on Fraudulent Finan- cial Statements}

The research result shows that company growth has a positive effect on fraudulent financial statements. This can occur because the manipulation of financial statements is committed to reducing the large tax burden. Increased growth indicates higher sales resulting in high profits. High profits result in a large tax burden as well. With high sales conditions, the imposed income tax burden will be large, thus driving management to manipulate financial reports to produce a smaller income tax burden. The results support the research conducted by Amijaya \& Prastiwi (2013), Carcello \& Nagy (2004), and Albring et al.(2013) which show that company growth has a positive effect on the manipulation of financial statements.

\section{The Effect of Supervision Effectiveness on Fraudulent Financial Statement}

The research result shows that the effectiveness of supervision does not have an effect on fraudulent financial statements. This can be caused by the existence of a board of independent commissioners which is only carried out to comply with statutory provisions so that 
Table 2. Summary of Variable Operational

\begin{tabular}{|c|c|}
\hline Variables & Operational definition \\
\hline $\begin{array}{l}\text { Fraudulent finan- } \\
\text { cial statement }(Y)\end{array}$ & $\begin{array}{l}\text { Misstatements that arise as a result of deliberate } \\
\text { fraudulent financial reporting or omissions of } \\
\text { amounts or disclosures in financial disclosures to } \\
\text { deceive users of financial statements causing the } \\
\text { financial statements not to be presented in accor- } \\
\text { dance with generally accepted accounting prin- } \\
\text { ciples. (Statement on Auditing Standards AU Section } \\
\text { 316) }\end{array}$ \\
\hline
\end{tabular}

Company growth A situation that describes the ability of an entity $\left(\mathrm{X}_{1}\right)$ to maintain its position in the economy. (Saputri et al., 2017)

The effectiveness A situation where a company has a monitoring of supervision system and implements effective monitoring of the $\left(\mathrm{X}_{2}\right)$ state and performance company. (Narolita \& Krisnadewi, 2016)

Quality of exter- The possibility of external auditors to avoid audit nal auditors $\left(\mathrm{X}_{3}\right) \quad$ failure. (Halbouni et al., 2016)

Director Experi- How long have board members served as directors ence $\left(\mathrm{X}_{4}\right)$ of the company concerned. (Chtourou et al., 2001)

CEO duality $\left(\mathrm{X}_{5}\right)$

A situation where there is a kinship relationship between a board of directors and a board of commissioners. (Putri \& Deviesa, 2017)

Audit committee One of the company organs under the board of (Z) commissioners that assists the board of commissioners in supervising the presentation of corporate financial information. (Ika \& Ghazali, 2012)
$\mathrm{X}_{1}=$ (total revenue $(\mathrm{t})$-total revenue $(\mathrm{t}-$ 1))/(total revenue $(\mathrm{t}-1))$

(Saputri et al., 2017)

$M$ score. Code 1 (one) for companies with a value of $\geq-2.22$ and code 0 (zero) for companies with a value of $<-2.22$ (Tiffani \& Marfuah, 2015)

$\mathrm{X}_{2}=$ number of independent commissioners / total board of commissioners (Kusumawardhani, 2013)

Code 1 if the company is audited by KAP with a market share of $\geq 15 \%$. Code 0 if the company is audited by KAP with a market share $<15 \%$. (Rusmin, 2010)

$\mathrm{X}_{4}=$ total work period of members of the board of directors/number of members of the board of directors (Chtourou et al., 2001)

Code 1 for companies that have a kinship relationship between the board of directors and the board of commissioners. Code 0 for companies that have no kinship between the board of directors and the board of commissioners.

(Putri \& Deviesa, 2017)

Total audit committee meetings in a year.

(Wicaksono \& Chariri, 2015) it is less effective in enforcing good corporate governance. In addition, it is possible that the members of the independent commissioner have not been involved in this field for a long time so that the duties and roles are not yet effective. Therefore, the higher the proportion of board of independent commissioners does not necessarily minimize the occurrence of fraudulent financial statements. This finding supports the research conducted by Setiawati \& Baningrum (2018) and Yang et al.(2017) which explain that the effectiveness of supervision does not affect the manipulation of financial statements.

\section{The Effect of External Auditor Quality on Fraudulent Financial Statement}

The research result shows that the quality of external auditors does not affect fraudulent financial statements. This is probably since both industry-specialist auditors and not are bound by the public accountant's code of ethics so that both are always required to carry out audits as well as possible. It is the responsibility of all auditors to ensure that the financial statements are free from material misstatement. Thus, the industry-specialist auditors have not been able to be used as a proxy to measure the quality of external auditors. In addition, it is also since there are only a few companies that use industry-specialist auditors. This finding supports the research conducted by Aini \& Sulhani (2017) and Indarto \& Ghozali (2016) which reveal that the quality of external auditors has no effect on the manipulation of financial statements.

\section{The Effect of Director Experience on Fraudulent Fi- nancial Statement}

The research result shows that the experience of directors has no effect on fraudulent financial statements. The board of directors is the party responsible for running the company's operations. In addition, there is also a board of commissioners whose job is to monitor the performance of the board of directors. Thus, the length of time or not as a member of the board of directors 
Table 3. Summary of the hypothesis test results

\begin{tabular}{llccc}
\hline \multicolumn{1}{c}{ Hypothesis } & $\boldsymbol{\beta}$ & Sig & Results \\
\hline $\mathrm{H}_{1}$ & Company growth has a negative effect on fraudulent financial statements & 2.231 & 0.000 & Rejected \\
$\mathrm{H}_{2}$ & $\begin{array}{l}\text { The effectiveness of supervision has a negative effect on fraudulent financial } \\
\text { statements }\end{array}$ & -0.351 & 0.192 & Rejected \\
$\mathrm{H}_{3} \quad \begin{array}{l}\text { The quality of external auditors has a negative effect on fraudulent financial } \\
\text { statements }\end{array}$ & -0.203 & 0.563 & Rejected \\
$\mathrm{H}_{4} \quad \begin{array}{l}\text { Director experience has a positive effect on fraudulent financial statements } \\
\mathrm{H}_{5} \quad \text { CEO duality has a positive effect on fraudulent financial statements }\end{array}$ & -0.106 & 0.721 & Rejected \\
$\mathrm{H}_{6} \quad \begin{array}{l}\text { Audit committee weakens the relationship between company growth and fraud- } \\
\text { ulent financial statements }\end{array}$ & -1.675 & 0.006 & Accepted \\
$\mathrm{H}_{7} \quad \begin{array}{l}\text { Audit committee strengthens the relationship between the effectiveness of su- } \\
\text { pervision and fraudulent financial statements }\end{array}$ & 0.724 & 0.032 & Rejected \\
$\mathrm{H}_{8} \quad \begin{array}{l}\text { Audit committee strengthens the relationship between the quality of external } \\
\text { auditors and fraudulent financial statements }\end{array}$ & 0.315 & 0.444 & Rejected \\
$\mathrm{H}_{9} \quad \begin{array}{l}\text { Audit committee weakens the relationship between the experience of directors } \\
\text { and fraudulent financial statements }\end{array}$ & 0.853 & 0.039 & Accepted \\
$\mathrm{H}_{10}$ & $\begin{array}{l}\text { Audit committee weakens the relationship between CEO duality and fraudulent } \\
\text { financial statements }\end{array}$ & -0.310 & 0.568 & Rejected \\
\hline
\end{tabular}

Source: The results of data processing of SPSS 26, 2020

will still be supervised by the board of commissioners. The experience of directors is increasingly being used to overcome weaknesses and solve problems faced by the companies. Meanwhile, the recent work period can also be used to improve performance in order to maintain its position. Thus, with these conditions, the experience of the directors does not affect the occurrence of financial statement manipulation, such as the research conducted by Ratnasari \& Solikhah (2019) and Akbar(2017).

\section{The Effect of CEO Duality on Fraudulent Financial Statement}

The research result shows that CEO duality does not affect fraudulent financial statements. This condition is likely due to both the board of directors who have or do not have family relationships with the board of commissioners are aware of their functions and responsibilities in running the company. The family relationship owned does not push someone to commit fraudulent financial statements. However, these conditions can also be used to work together in overcoming problems experienced by the company. A CEO cannot abuse his power to commit fraud. Because after all, not all boards of directors and boards of commissioners have family relationships. Thus, when someone wants to act fraudulently; there are still other parties who can prevent it. This finding supports the research conducted by Akbar (2017) which reveals that CEO duality has no effect on the manipulation of financial statements.

\section{Audit Committee Moderates the Effect of Company Growth on Fraudulent Financial Statement}

The research result shows that the audit committee weakens the relationship between company growth and fraudulent financial statements. The audit committee has the authority and responsibility for reviewing financial information presented by the company to external parties. Through the supervision carried out, the audit committee can monitor the financial information to be presented so that if there are irregularities in the financial statements, the audit committee can understand this and prevent the financial statements presented with misstatements. Thus, the effect of company growth will be weaker with the presence of the audit committee. This result supports the research conducted by Santoso (2019) and Sugita (2018) which state that the audit committee is able to moderate the effect of the pressure factor on fraudulent financial statements.

\section{Audit Committee Moderates the Effect of Supervision Effectiveness on the Fraudulent Financial Statement}

The research result shows that the audit committee weakens the relationship between the effectiveness of supervision on fraudulent financial statements. This can occur because the board of independent commissioners and the audit committee are not independent in carrying out supervisory duties. This condition can be caused by the interference of certain parties on the element of supervision due to the element of power. This situation causes the audit committee to be unable to strengthen the corporate governance system in minimizing the possibility of fraudulent financial statements. This finding supports the research conducted by Murtanto \& Sandra (2019) which reveals that the audit committee weakens the relationship of the opportunity factor on the fraudulent financial statement.

\section{Audit Committee Moderates the Effect of External Auditor Quality on the Fraudulent Financial State- ment}

The research result indicates that the audit committee does not moderate the relationship between the 
quality of external auditors and the fraudulent financial statement. This condition is probably due to the weak coordination between the audit committee and the external auditors. Lack of information is also a factor in the failure of the audit committee which is unable to strengthen the relationship between the quality of external auditors in minimizing fraud. Both parties do not have a good relationship in carrying out their roles in the supervisory process of financial reporting. This finding supports the research conducted by Fathoni et al. (2020) which finds that the audit committee does not moderate the relationship between the quality of external auditors and earnings management.

\section{Audit Committee Moderates the Effect of the Direc- tors' Experience on the Fraudulent Financial State- ment}

The research result shows that the audit committee weakens the relationship between the experience of directors and fraudulent financial statements. The audit committee is responsible for monitoring follow-up management on internal audit findings. Thus, the audit committee supervises management activities in following up on internal audit findings and ensures that management has carried out its responsibilities properly in preparing financial reports, which in turn can minimize fraudulent financial statements. This finding supports the research conducted by Santoso (2019) and Mardiani et al.(2017) which reveal that the effect of the capability factor on fraudulent financial statements could be weakened by the audit committee.

\section{Audit Committee Moderates the Effect of CEO Dual- ity on Fraudulent Financial Statements}

The research result shows that the audit committee does not moderate the relationship between CEO duality and fraudulent financial statements. This is since the audit committee is an organ under the board of commissioners so it must be accountable for its work to the board of commissioners. The audit committee has smaller authority than the board of commissioners makes it difficult for the audit committee to minimize the element of power that occurs in the company. Thus, the effect of CEO duality has not been able to be weakened by the presence of the audit committee. This finding supports the research conducted by Santoso (2019) which reveals that the audit committee does not moderate the effect of the arrogance factor on fraudulent financial statements.

\section{CONCLUSIONS}

The research results show that company growth has a positive effect on fraudulent financial statements. Meanwhile, the effectiveness of supervision, the quality of external auditors, the experience of directors, and CEO duality do not affect fraudulent financial statements. The audit committee weakens the effect of company growth, the effectiveness of supervision, and the experience of the directors on fraudulent financial statements. The audit committee does not moderate the effect of the external auditor quality and CEO duality on fraudulent financial statements. This study suggests that companies intensify audit committee meetings to minimize fraudulent financial statement practices. A suggestion for potential investors to be more careful with companies with high sales growth. Further research is suggested to use other measurement methods for independent variables. This is because many of the measurement methods used in this study have not provided empirical evidence of their effect on fraudulent financial statements.

\section{REFERENCES}

Aini, N., \& Sulhani. (2017). Upaya Pendeteksian Fraud Melalui Analisis Fraud Diamond dan Kualitas Audit. Simposium Nasional Akuntansi XX, 1-29.

Akbar, T. (2017). The Determination of Fraudulent Financial Reporting Causes by Using Pentagon Theory on Manufacturing Companies in Indonesia. International Journal of the Economics of Business, 14(5), 106-113.

Albrecht, C., Skousen, C., Turnbull, C., \& Zhang, Y. (2010). The Relationship Between South Korean Chaebols and Fraud. Management Research Review, 33(3), 257-268.

Albring, S. M., Huang, S., Pereira, R., \& Xu, (2013). The Effects of Accounting Restatements on Firm Growth. Journal of Accounting and Public Policy, 32(5), 357376.

Amijaya, M. D., \& Prastiwi, A. (2013). Pengaruh Kualitas Audit Terhadap Manajamen Laba. Diponegoro Journal of Accounting, 2(3), 1-13.

Apriliana, S., \& Agustina, L. (2017). The Analysis of Fraudulent Financial Reporting Determinant Through Fraud Pentagon Approach. Jurnal Dinamika Akuntansi, 9(2), 154-165.

Association of Certified Fraud Examiners. (2018). Report to the Nations 2018 Global Study on Occupational Fraud and Abuse. USA: ACFE.

Carcello, J. V., \& Nagy, A. (2004). Audit Firm Tenure and Fraudulent Financial Reporting. Journal of Service Theory and Practice, 23(2), 55-69.

Chtourou, S. M., Bedard, J., \& Courteau, L. (2001). Corporate Governance and Earnings Management. Social Sciences and Humanities Research Council of Canada, 10(2), 40-55.

Dobson, J. (1993). Moral Hazard, Adverse Selection and Reputation: A Synthesis. Managerial Finance, 19(6), 2-8.

Fathoni, R. F., \& Prasetyo, A. (2020). Pengaruh KAP Spesialis Industri, KAP Big Four dan Masa Perikatan Auditor Terhadap Manajemen Laba Dengan Efektivitas Komite Audit Sebagai Variabel Moderasi Pada Perusahaan Non-Keuangan di BEI Tahun 2016. Diponegoro Journal of Accounting, 9(2), 1-10.

Halbouni, S. S., Obeid, N., \& Garbou, A. (2016). Corporate Governance and Information Technology in Fraud Prevention and Detection:Evidence from the UAE. Managerial Auditing Journal, 31(6-7), 589-628.

Ika, S. R., \& Ghazali, N. (2012). Audit Committee Effectiveness and Timeliness of Reporting: Indonesian Evidence. Managerial Auditing Journal, 27(4), 403-424.

Indarto, S. L., \& Ghozali, I. (2016). Fraud Diamond: Detecting Analysis on the Fraudulent Financial Reporting. Risk Governance \& Control: Financial Markets \& Institutions, 6(4), 85-159.

Jensen, M. C., \& Meckling, W. H. (1976). Theory of the Firm: Managerial Behaviour, Agency Costs and Ownership 
Structure. Journal of Financial Economics, 3(4), 305360 .

Kusumawardhani, P. (2013). Deteksi Financial Statement Fraud Dengan Analisis Fraud Triangle Pada Perusahaan Perbankan Yang Terdaftar Di BEI. Jurnal Akuntansi Unesa, 1(3), 1-16.

Mardiani, S., Sukarmanto, E., \& Maemunah, M. (2017). Pengaruh Fraud Diamond Terhadap Pendeteksian Financial Statement Fraud Dengan Komite Audit Sebagai Variabel Moderasi. Prosiding Akuntansi, 3(2), 476484.

Marks, J. (2012). The Mind Behind The Fraudsters Crime:Key Behavioral and Environmental Elements. Crowe Horwath. Diunduh dari: http://www.fraudconference. com/uploadedFiles/Fraud_Conference/Content/ Course-Materials/presentations/23rd/ppt/10C-Jonathan-Marks.pdf pada 1 Oktober 2020.

Murtanto, \& Sandra, D. (2019). Pengaruh Fraud Diamond Dalam Mendeteksi Tingkat Accounting Irregularities. Jurnal Media Riset Akuntansi, Auditing \& Informasi, 19(2), 209-226.

Narolita, E., \& Krisnadewi, K.A. (2016). Pengaruh Penerapan Corporate Governance Pada Manajemen Laba Oleh Chief Executive Officer Baru. E-Jurnal Akuntansi Universitas Udayana, 14(1), 635-662.

Prasetyo, A.B. (2014). Pengaruh Karakteristik Komite Audit dan Perusahaan Terhadap Kecurangan Pelaporan Keuangan (Studi Empiris Pada Perusahaan Yang Listed di BEI Periode 2006-2010). Jurnal Akuntansi \& Auditing, 11(1), 1-24.

Rahman, R.A., \& Anwar, I.S.K. (2014). Effectiveness of Fraud Prevention and Detection Techniques in Malaysian Islamic Banks. Procedia - Social and Behavioral Sciences, 145(2), 97-102.

Ratnasari, E., \& Solikhah, B. (2019). Analysis of Fraudulent Financial Statement: The Fraud Pentagon Theory Approach. Gorontalo Accounting Journal, 2(2), 98-112.

Rusmin, R. (2010). Auditor Quality and Earnings Management: Singaporean Evidence. Managerial Auditing Journal, 25(7), 618-638.

Saleh, J.M.N. (2010). Fraudulent Financial Reporting and Company Characteristics: Tax Audit Evidence. Journal of Financial Reporting and Accounting, 8(2), $128-142$.

Santoso, S.H. (2019). Fenomena Kecurangan Laporan Keuangan Pada Perusahaan Terbuka di Indonesia. Jurnal Magister Akuntansi Trisakti, 6(2), 173-200.

Saputri, Y., Auliyah, R., \& Yuliana, R. (2017). Pengaruh Nilai Perusahaan, Pertumbuhan Perusahaan, Reputasi Auditor Terhadap Perataan Laba di Sektor Perbankan. Neo-Bis, 11(2), 121

Setiawati, E., \& Baningrum, R. M. (2018). Deteksi Fraudulent Financial Reporting Menggunakan Analisis Fraud Pentagon : Studi Kasus Pada Perusahaan Manufaktur Yang Listed di BEI Tahun 2014-2016. Riset Akuntansi Dan Keuangan Indonesia, 3(2), 91-106.

Smaili, N., \& Labelle, R. (2016). Corporate Governance and Accounting Irregularities: Canadian Evidence. Journal of Management and Governance, 20(3), 625-653.

Sugita, M. (2018). Peran Komite Audit Sebagai Variabel Moderasi Terhadap Hubungan Fraud Diamond dan Pendeteksian Financial Statement Fraud. Jurnal Online Mahasiswa (JOM) Bidang Ilmu Ekonomi, 1(1), 1-15.

Uciati, N., \& Mukhibad, H. (2019). Fraudulent Financial Statements at Sharia Banks. Accounting Analysis Journal, 8(3), 198-206.

Wicaksono, G.S., \& Chariri, A. (2015). Mekanisme Corporate
Governance dan Kemungkinan Kecurangan Dalam Pelaporan Keuangan. Diponegoro Journal of Accounting, 4(4), 552-563.

Wolfe, D.T., \& Hermanson, D.R. (2004). The Fraud Diamond : Considering the Four Elements of Fraud: Certified Public Accountant. The CPA Journal, 74(12), 38-42.

Yang, D., Jiao, H., \& Buckland, R. (2017). The Determinants of Financial Fraud in Chinese Firms: Does Corporate Governance as an Institutional Innovation Matter? Technological Forecasting and Social Change, 125(2), 309-320. 